\title{
MANAGING ICT ACCESS AND TRAINING FOR EDUCATORS
}

\author{
A Case Study
}

Christopher O'Mahony

Information Systems Manager - The Royal High School, BATH, UK

\begin{abstract}
This paper reports on a study investigating the use of ICT (Information and Communication Technology) by academic and non-academic staff at an independent English secondary school. Three key areas were investigated: access to ICT inside and outside the school, the perceived and desired ICT ability of staff, and issues preventing increased use of ICT in teaching, learning and administration. Results showed that a major challenge facing the school was not access to ICT resources, but the provision of relevant supportive training for staff.
\end{abstract}

Key words: School information systems, professional development, educational management, information and communication technology

\section{INTRODUCTION}

As secondary schools across Britain get more serious about ICT strategic planning, it is important to build in regular evaluation points to assess the efficacy of ICT investments and management structures (Baker 1995, O'Mahony et al. 1996). In addition to providing a basic level of ICT hardware and software, many schools recognise the importance of staff ICT training. Ability must go hand-in-hand with access, thus leading to confident use of resources for teaching, learning and administration. At the same time, schools are continually challenged to respond to technological change - realising the potential of e-learning innovations.

Research concerning ICT professional development for teachers already exists (Mumtaz 2000), and many exemplary initiatives have been attempted

The original version of this chapter was revised: The copyright line was incorrect. This has been corrected. The Erratum to this chapter is available at DOI: 10.1007/978-0-387-35689-1_19 
around the world, such as the TILT programme in Australia, and the NOF scheme in the UK (Selwood et al. 2000). Broad-brush initiatives such as these are a useful starting point, but it is noted that staff ICT training must be customised to the needs of individual schools, and individual staff (McDougall \& Squires 1997).

This paper presents the results of a survey conducted in September 2001 at an independent girls day and boarding school in the West of England (School X). The survey sought to investigate three things: staff levels of access to ICT both at home and at work; staff levels of use of ICT both at home and at work; and staff perceptions of ability with a variety of ICT applications. Drawing on the work of previous research (McDougall \& Squires 1997; Cox et al. 1999; Mumtaz 2000; O’Mahony 2000), research questions were formulated as follows:

- What are the current levels of access to ICT resources among school staff and students?

- What are the current levels of ability with ICT among school staff?

- What are the current levels of use of ICT resources among school staff?

Results indicate that although access to ICT resources is high, staff at School X can improve their integration of ICT use in teaching, learning and administration. High levels of access to ICT resources are reported, well above national averages indicated by Watson et al. (1998). At the same time, despite concentrated pockets of ICT use, the majority of staff use these resources infrequently. The level of ICT training is perceived as low, with the main criticism being a lack of time available for training.

A key element of this study is a reliance on action research methodologies (Hult \& Lennung 1980). To this end, conclusions of the paper include practical recommendations for training programmes, homeschool network links and carefully targeted ICT resourcing. Although much has been invested, the challenge now is to reap the return on the investment.

\section{BACKGROUND}

School $\mathrm{X}$ is a member of a Trust of independent girls schools (the XYZ Trust). In 1995, the XYZ Trust made a significant commitment to ICT in its schools. At that time, it embarked on a policy which included a strong investment in ICT infrastructure, including LANs in each school and a Wide Area Network connecting all Trust sites, investments in software and hardware, staff training and ICT management mechanisms. A rollout of ISDN connections was completed in 1997, providing data communications links between schools and Trust Office, as well as access to Trust-wide email services and to the Internet. Local Area Networks in individual 
schools progressed simultaneously, funded centrally. To make effective use of this infrastructure, the Trust set aside funding on a per capita basis for each school, designed to cover purchasing of PCs and other peripherals, software licenses, consumables, staff training and ongoing maintenance.

An important element of the Trust's initiative was the establishment of IS management posts in each school. Historically, like many other schools, the Trust had relied on enthusiastic teaching staff to provide technical ICT support. As time passed and ICT became more complex and more pervasive, the Trust recognised the need for full-time technical support. By 1998, all Trust schools had either an Information Systems Manager or Network Manager and at least one ICT technician.

School X, as a member of the XYZ Trust, has been a beneficiary of the ICT initiative. Between 1995 and 2001, the number of PCs at the school rose from 40 to 200 , connected by a single NT network. All staff and students have personal email addresses provided by the school, the school's administrative information systems have been streamlined, and ICT is in evidence in almost all teaching and learning (School X 2001).

In November 2000, the school was the subject of an Independent Schools Inspection. Despite praising the school in many areas, the inspectors commented that ICT could be better used throughout the school (ISI 2000). The issue for inspectors was not so much quantitative metrics on ICT resources in the school, but rather more qualitative measures as to the effectiveness of those resources. In September 2001, members of the school's senior management team engaged in a whole-school consultation for strategic development, of which ICT was a contributing factor. Part of this consultation included surveys of both staff and students regarding ICT use and ability. Interim results from these surveys are the subject of this paper.

\section{METHODOLOGY}

Two surveys were administered to the school community at the beginning of the Autumn Term 2001. A Staff Survey was administered on September 5, 2001, during a full staff study day. 96 responses were received, representing $100 \%$ of the school's staff population. On October 9 , 2001, a Student Survey was administered through form group assemblies. In total, 426 responses were received, representing $71 \%$ of the senior school's student population (Year groups 7 to 13). Responses to both surveys were entered into automated spreadsheets for analysis.

The primary focus of the surveys was their practical element. They were designed to provide swift and immediate feedback to the school's senior 
management team, enabling them to tailor their ICT strategic planning for the forthcoming years. In this sense, the study had a strong Action Research dimension (Baskerville \& Wood-Harper 1996; Klein \& Myers 1999). The research provided important signposts for the provision of appropriate access to ICT resources in the school, the provision of customised training programmes for staff, and the fine-tuning of limited ICT budgets to areas so identified.

At the same time, despite the pragmatic nature of the study, every attempt was made to retain academic rigour in the study (Benbasat \& Zmud 1999; Kock et al. 1997; Lee 1999). Survey questions were drawn from a bank of questions already used in previous studies by National Statistics (2000), BECTA (2000, 2001a, 2001b) and Research Machines (2000), giving a strong validity to the survey instruments. The use of a survey methodology in itself enables repeatability (Leedy 1993). All survey responses were anonymous and confidential, with no possibility of identifying specific individuals.

Limitations certainly exist. It must be noted that the school's student population is all female, which will have some bearing on the results. Furthermore, consideration should be given to the socio-economic status of both students and staff at the school. The area in which School.X is located is generally considered an affluent area, and the school, although offering competitive fees, has a specific position in the local educational market. To this end, it is recommended that a geographically wider study, using the same tools, will give a much more comprehensive answer to the research questions.

\section{RESULTS}

Results drawn from the surveys fall naturally into the broad categories proposed in the instruments, and are treated accordingly here as follows:

- Access to ICT at home- questions 1 to 5 - section 4.1

- Access to ICT at work - questions 6 to 9 - section 4.2

- Use of ICT - questions 10 to 15 - section 4.3 and 4.4

- Ability with ICT - questions 16 and 17 - section 4.5

- Difficulties with ICT - question 18 - section 4.6.

\subsection{Access to ICT at home}

Overall, results drawn from both the staff and student surveys indicated that access to ICT resources was significantly higher than the national average. $92 \%$ of staff had access to a computer at home, much higher than 
the national average of $40 \%$ of households (Tables $12-1$ and $12-2$ ). $77 \%$ of staff had access to the internet from home, as compared with a national average of $38 \%$. For students, the equivalent survey results showed that $91 \%$ of students had access to a computer at home, and $85 \%$ had access to the Internet from home.

Table 12-1. Home access to computers (Sources: National Statistics 2000, National Grid for Learning 2001)

\begin{tabular}{lcccc}
\hline & $\%$ Staff & $\%$ Students & $\begin{array}{c}\text { Impact2 } \\
\text { Average }\end{array}$ & $\begin{array}{c}\text { National } \\
\text { Average }\end{array}$ \\
\hline Senior School & $91 \%$ & $91 \%$ & $\mathrm{n} / \mathbf{a}$ & \\
Junior School & $95 \%$ & $\mathrm{n} / \mathrm{a}$ & $\mathrm{n} / \mathrm{a}$ & \\
TOTAL & $92 \%$ & $91 \%$ & $\mathrm{n} / \mathrm{a}$ & $40 \%$ \\
\hline
\end{tabular}

Table 12-2. Home access to the Internet (Sources: National Statistics 2000, National Grid for Learning 2001)

\begin{tabular}{lcccc}
\hline & \% Staff & \% Students & $\begin{array}{c}\text { Impact2 } \\
\text { Average }\end{array}$ & $\begin{array}{c}\text { National } \\
\text { Average }\end{array}$ \\
\hline Senior School & $78 \%$ & $85 \%$ & $64 \%$ & \\
Junior School & $75 \%$ & $\mathrm{n} / \mathrm{a}$ & $48 \%$ & \\
TOTAL & $77 \%$ & $\mathbf{8 5 \%}$ & & $38 \%$ \\
\hline
\end{tabular}

In commenting on this surprisingly high penetration of ICT into the homes of school staff and students, closer inspection of the demographics is recommended. It is worth noting that, since 1997, the XYZ Trust has been promoting the use of interest-free loans for personal computer purchases by staff. A good number of staff had taken up this offer, which has clearly helped to raise the proportion of home ICT equipment among staff. Another hypothesis is that a significant number of staff were themselves members of families with school-age children, thus suggesting additional incentives for purchasing ICT equipment for home use.

Research conducted during the Impact2 study (National Grid for Learning 2001) suggests a strong correlation between staff access to ICT at home and staff confidence and competence with ICT. Given the high proportion of both staff and students with access to computers at home, it is interesting to consider the responses to questions regarding actual use of these resources. Analysis of this response is presented in section 4.3.

\subsection{Access to ICT at work}

In comparison to home access to ICT, it is worth considering access to ICT provided within the school walls (Table 12-3). As already noted in the introduction to this paper, the XYZ Trust has been investing heavily in ICT since around 1995. As a result, it now boasts an enviable student-to- 
computer ratio across all its schools. At School X, this stood at 1:6 in 2001, significantly higher than the most recently published national averages (Table 12-4). Staff access to computers at school was also high, with a staffto-computer ratio of 1:2 in 2001. Other key indicators include the amount of expenditure per capita on ICT (Table 12-5), and the number of individual email addresses provided by the school (Table 12-6).

Table 12-3. School Access to ICT

\begin{tabular}{lccc}
\hline School Access to: & All Staff & Senior & Junior \\
\hline PC & $84.38 \%$ & $83 \%$ & $95 \%$ \\
Email & $93.80 \%$ & $96 \%$ & $95 \%$ \\
Internet & $95.83 \%$ & $92 \%$ & $95 \%$ \\
\hline
\end{tabular}

Table 12-4. Computer-to-Student Ratios

\begin{tabular}{lccc}
\hline Ratios & 1999 & 2000 & 2001 \\
\hline School X & 7.0 & 6.5 & 6.0 \\
National Average & 8.4 & 7.9 & n/a \\
\hline
\end{tabular}

Table 12-5. ICT Expenditure per Capita (1999-2001)

\begin{tabular}{lccc} 
& 1999 & 2000 & 2001 \\
\hline School X & $£ 77$ & $£ 77$ & $£ 130$ \\
National Average & $£ 45$ & $£ 47$ & n/a \\
\hline
\end{tabular}

Table 12-6. Access to Email

\begin{tabular}{lcc} 
& Teachers & Students \\
\hline School X & $100 \%$ & $100 \%$ \\
Impact2 Average & $\mathrm{n} / \mathrm{a}$ & $67 \%$ \\
National Average & $52 \%$ & $26 \%$ \\
\hline
\end{tabular}

\subsection{Use of ICT at home}

On average, staff used a home computer for 4 hours per week for schoolbased tasks, and a further 2 hours per week for non-school based tasks. Staff used their home Internet account for about $1 \mathrm{hr} 45$ minutes each week - 1 hour for personal use and $\mathbf{4 5}$ minutes for school tasks. A distinct difference was noted between home ICT use by junior school staff as opposed to their senior school counterparts (Table 12-7).

Table 12-7. Home use of ICT (hours per week) - All Staff

\begin{tabular}{lccc|ccc}
\hline & \multicolumn{3}{c|}{ For Work } & \multicolumn{3}{c}{ Not for Work } \\
\hline & $\begin{array}{c}\text { Junior } \\
\text { School }\end{array}$ & $\begin{array}{c}\text { Senior } \\
\text { School }\end{array}$ & Combined & $\begin{array}{c}\text { Junior } \\
\text { School }\end{array}$ & $\begin{array}{c}\text { Senior } \\
\text { School }\end{array}$ & Combined \\
\hline Using the Computer & 2.63 & 4.19 & 3.86 & 1.13 & 2.12 & 1.91 \\
Using the internet & 0.78 & 0.69 & 0.71 & 0.93 & 1.04 & 1.01 \\
Using email & 0.40 & 0.75 & 1.01 & 0.85 & 1.11 & 1.05 \\
\hline
\end{tabular}




\subsection{Use of ICT at work}

On average, staff used a work computer for 7.65 hours per week on school-based tasks. About one hour each week was spent using the Internet at work (Table 12-8).

Table 12-8. Work use of ICT (hours per week) - All Staff

\begin{tabular}{lccc|ccc}
\hline & \multicolumn{3}{c|}{ For Work } & \multicolumn{3}{c}{ Not for Work } \\
\hline & $\begin{array}{c}\text { Junior } \\
\text { School }\end{array}$ & $\begin{array}{c}\text { Senior } \\
\text { School }\end{array}$ & Combined & Junior & Senior & Combined \\
School & School & \\
\hline Using the Computer & 2.00 & 7.65 & 6.51 & 0.05 & 0.10 & 0.09 \\
Using the internet & 0.55 & 1.24 & 0.90 & 0.00 & 0.08 & 0.06 \\
Using email & 1.22 & 0.08 & 1.10 & 0.11 & 0.13 & 0.13 \\
\hline
\end{tabular}

When responses from administrative staff were eliminated, however, the results for teaching staff were markedly reduced (Table 12-9). The large difference in average ICT work use between academic and administrative staff demanded closer investigation. For academic respondents, 90\% claimed to use ICT for less than 10 hours per week - 75\% reported less than 5 hours per week. This result begged the question - if access to resources was so high, why was use so low? Part of the answer to this question lay in the responses to subsequent components of the questionnaire.

Table 12-9. Work use of ICT (hours per week) - Administrative vs. Academic staff

\begin{tabular}{lcc|cc}
\hline & \multicolumn{2}{c|}{ For Work } & \multicolumn{2}{c}{ Not for Work } \\
\hline & Admin & Academic & Admin & Academic \\
\hline Using the Computer & 20.4 & 4.86 & 0.10 & 0.09 \\
Using the internet & 0.1 & 1.22 & 0.00 & 0.07 \\
Using email & 4.2 & 1.75 & 0.03 & 0.14 \\
\hline
\end{tabular}

\subsection{Ability}

The second half of the staff questionnaire considered ICT ability among staff. Question 16 asked staff to rate their current perceived ability with a range of ICT hardware and software. On each of ten items, staff were asked to self-assess their ability in the range $0-3$, where 0 signified no ability, and 3 signified expert ability.

A wide range of ability was perceived across departments. Of key concern to the school was any department with an "average" score of less than 0.70. Although perceived ability with items such as email and Word was relatively high, other items that have a growing relevance to teaching and learning were relatively weak. By sorting the data in this way, the school was able to consider training solutions that targeted specific departments, rather than more broad-brush approaches. Using this ranking, 
it was interesting to note that ICT ability was broadly spread across subjecttypes. That is, contrary to conventional wisdom, it was not necessarily the 'soft' humanities subjects claiming low ICT ability, and not necessarily the 'hard' numerate subjects claiming high ICT ability. This would indicate that results were driven more by personalities involved, rather than subject stereotypes.

Question 17 asked staff to nominate their desired ability with the same range of items. We took the difference between perceived current ability and desired future ability for each respondent, (that is, Q16 response versus Q17 response) and summed this difference for each application. Results suggested that the school's top training priorities were as follows (Table 1210). It was pleasing to note that topics classified as more 'basic', such as email, word processing and web searching, came at the bottom of the list. This indicated that staff were generally comfortable with these basic applications, but were also keen to move ahead.

Table 12-10. Training priorities

\begin{tabular}{|c|c|}
\hline Application & Priority \\
\hline Powerpoint & 1 \\
\hline Data Projectors & 2 \\
\hline Web Design & 3 \\
\hline Microsoft Publisher & 4 \\
\hline Digital Whiteboards & 5 \\
\hline Microsoft Access & 6 \\
\hline Microsoft Excel & 7 \\
\hline Web Searching & 8 \\
\hline Microsoft Word & 9 \\
\hline Email & 10 \\
\hline
\end{tabular}

The top five training priorities all had a strong focus on teaching and learning, being directly applicable to classroom practice. Their position in the list indicates a desire to incorporate more sophisticated use of ICT into lessons.

It should be noted that since 1996, the school had attempted a number of ICT training initiatives. These ranged from informal self-help style sessions for small groups, through to formal structured training programmes away from the school premises. Such initiatives had varying success, but clearly the baseline for staff ICT ability was gradually improving. Further discussion of staff ICT ability and appropriate training models is given in Section 5.3. 


\subsection{Perceived difficulties}

Respondents were asked to rank ten common issues in terms of their importance to them - "What's holding you back in your use of ICT in the school?" Responses to this question were occasionally incomplete, but sufficient data was collected to give confidence in the analysis. Not surprisingly, the results are in sympathy with other research in this area (Mumtaz 2000). Across the school, the top concerns were as follows (Table 12-11).

Table 12-11. Staff ICT Concerns

\begin{tabular}{lc}
\hline \multicolumn{1}{c}{ Concern } & Rank \\
\hline Time & 1 \\
Quantity of classroom ICT resources & 2 \\
Quantity of ICT training & 3 \\
Quality of classroom ICT resources & 4 \\
Quantity of staff ICT resources & 5 \\
\hline
\end{tabular}

\section{DISCUSSION}

It is clear from the survey results and from supporting evidence that the school has made some positive moves with ICT. Expenditure on ICT resources has been significant, continuous and carefully targeted. This has given both staff and students a high level of access to ICT, matched by high levels of access in the home.

At the same time, staff reported relatively low levels of ICT use, both in home and school environments. Staff ICT ability had moved beyond the 'beginner' stage, but staff were expressing difficulty in gaining skills with more sophisticated tools such as presentation graphics, desktop publishing and web publishing. Key issues for staff, preventing the achievement of this objective, included a lack of time, a lack of training, and a lack of ICT resources in the classroom.

\subsection{Immediate action}

In terms of action research, results from this study provided immediate and practical feedback to the school's ICT strategic planning. For instance, it was clear that a proposed laptop programme was not required, given such a high proportion of computer access at home already. Instead, attention shifted to possibilities for promoting home-school access. Providing access from home to school network resources through a Virtual Private Network appeared to be a necessary and desirable step. 
Responding to staff perceived ICT difficulties, school management incorporated many of the outcomes into its wider development planning. Access to staff ICT resources was addressed quickly, with additional highspecification PCs installed in staff areas. The ICT training programme was revisited to target staff's stated priorities, rather than broad-brush introductory skills training. A project was established to re-design the school's intranet, introducing more dynamism and incorporating e-learning principles. To address concerns regarding classroom access to ICT, a project was established to investigate installing a humanities-specific ICT suite for 2002.

One of the more exciting outcomes of the study was the re-launch of the school's ICT Working Party. In order to attract new blood and new enthusiasm, staff nominated for membership were offered one hour's time release per fortnight, to be used for exploring innovative teaching strategies. At the same time, they were offered priority specialised ICT training. It was anticipated that these 'seeds' would then pass on their strategies and newfound skills to colleagues.

\subsection{ICT effectiveness model}

In synthesising the results drawn from the two questionnaires, it is possible to develop a model for school ICT effectiveness. This model is presented here as a 6-point plan for achieving confident use with ICT. In summary, the 6-point-plan comprises:

- Resources

- Policy

- Departmental commitment

- Training Programme

- Evaluation/appraisal

- Student learning

These six 'pillars' are outlined in the sections following.

\subsubsection{ICT resources}

A pre-requisite to success with school ICT is the provision of sufficient resources. These resources include network infrastructure, workstation and peripheral hardware, software and human resources. Strong project management must be applied to ensure that the school gains good value for money, at the same time recognising that inferior products do more damage than good. Where possible, hardware and software applications must be well integrated and easy to use (Stevenson 1997). 


\subsubsection{Curriculum ICT policy (Strategic)}

The school must make a clear statement of intent and direction concerning the use of information and communication technologies in curriculum areas. This statement must be visible in school documentation at the senior management level, and be internalised throughout the curriculum. The curriculum ICT policy must articulate well with the school's business and strategic development plans. Specific details of this policy could include a mandated minimum number of hours of ICT use, a target minimum qualification to be attained, or specific ICT-based assessment tasks.

\subsubsection{Department commitment (Tactical)}

At the Department level, ICT policies must exist which articulate with the wider ICT strategy, and provide necessary detail and context for the respective curriculum area. This policy should express the department's commitment to ICT professional development, and specify expectations of ICT use in the classroom, both in terms of minimum hours and ICT-based tasks.

\subsubsection{Teacher professional development}

As well as having ICT resources, and having policies regarding the use of ICT in teaching, learning and administration, a robust and measurable professional development programme must be in place. Of course, a teacher's skill with ICT should begin pre-service. This is an area where, in the past, teacher-training institutions have been remiss. As employers, schools have a right to expect training institutions to effectively prepare graduates for the whole classroom experience, which increasingly includes confidence and competence with ICT. One way that this expectation is being made manifest is in job advertisements, which more frequently make explicit reference to ICT skill requirements.

Whatever the pre-existing experiences of staff, an internal professional development programme should, as a starting-point, comprehensively and continuously audit their ICT skill-set. The implementation of an ICT training regime will vary from school to school. Decisions need to be made concerning appropriate venues for training (within school or away from school), timing (within school time or out of school hours) and content (productivity-based or subject-specific). Hiring external trainers has often been the only option for schools but, increasingly, schools are considering the appointment of dedicated training staff within the overall ICT function (O’Mahony 2001). 


\subsubsection{Staff appraisal and review}

The appraisal and review process gives crucial feedback for all aspects of the model. To drive home the message concerning the school's commitment to ICT, effective classroom use of ICT must become a performance indicator for staff. A process must exist whereby the reviewer can flag the reviewee's ICT training needs. This must be communicated to the training function / coordinator, who organises / delivers the required training. Once completed, confirmation of training is passed back along the chain.

As well as providing feedback on staff ability, the appraisal and review process offers the opportunity to flag any issues concerning ICT resourcing or access. These issues, too, must be forwarded to the relevant person / function. Collectively, these items will assist in the formation of subsequent ICT strategies.

\subsubsection{Student ICT literacy}

The ultimate aim of this model, and in particular the Staff ICT professional development programme, is the improvement of student learning. Thus, complementary to a Staff ICT skills programme is a crosscurricular student ICT skills programme. Transcending the use of ICT in specific subjects, such a programme would provide broad-based exposure to generic ICT skills, including keyboard familiarity, word processing, spreadsheets, presentation graphics, internet searching and 'appropriate ICT use'.

\section{CONCLUSION}

The Trust's (and the school's) explicit investment in ICT is demonstrably effective - the ratio of computers-to-students is low, and staff note a satisfying level of access to ICT resources for teaching and learning. At the same time, and generally outside the influence of the school, both staff and students have a high level of access to computers and the Internet from their homes.

In terms of ability, the majority of staff at the school have progressed beyond the 'beginner' stage, and are seeking to broaden and deepen their ICT skills.

Although reporting high access to ICT resources at both home and work, staff note an unremarkable low level of use of these resources. National statistics data shows a general rise in home ICT use across the country, but despite recognition that there is a growing obligation and desire to 
incorporate ICT elements into teaching and learning, including lesson preparation, teachers report concerns with training and the amount of time available to improve their skills with ICT.

Results from the study are comparable to results reported by other researchers. Like McDougall \& Squires (1997) and Visscher \& Brandenhorst (2000), it is clear that a well-defined programme for professional development is crucial to success with ICT in the classroom. Like Mumtaz (2000) and Cox et al. (1999), a number of factors exist which inhibit teachers from successful experiences with ICT in the classroom.

Many questions remain. For instance, although staff have a high level of access to ICT at home, a significant minority still do not. $8 \%$ of staff do not have a computer at home $-23 \%$ do not have access to the Internet at home. How does the school respond to this? How can these staff be encouraged? How should the school best allocate its resources to close this gap? Similarly, with students, $15 \%$ still have no home access to the Internet. What implications does this have for home-school ICT access? What implications does this have for their academic progress?

Two key recommendations are made from this study. The first is that the school maintains its commitment to continuous improvement, with and through ICT. The second is that a wider study should be performed, across all XYZ Trust schools in the first instance, to provide a more comprehensive picture of ICT efforts in this unique organisation.

\section{REFERENCES}

Baker, B., (1995). The role of feedback in assessing information systems planning effectiveness. Journal of Strategic Information Systems. 4, 1, 1995.

Baskerville, R.L., Wood-Harper, T., (1996). A critical perspective on action research as a method for information systems research. Journal of Information Technology. 1996, 11, pp235-246.

BECTA (2000). Connecting Schools, Networking People: ICT planning, purchasing and good practice for the national Grid for Learning. British Educational Communications and Technology Agency, Coventry.

BECTA (2001a). Primary Schools of the Future - Achieving today. A report to the DfEE by Becta. British Educational Communications and Technology Agency, Coventry.

BECTA (2001b). The Secondary School of the Future. A preliminary report to the DfEE by Becta. British Educational Communications and Technology Agency, Coventry.

Benbasat, I., \& Zmud, R., (1999). Empirical research in Information Systems: the practice of relevance. MISQ, Vol 23, No 1, March 1999, pp 3-16.

Cox, M., Preston, C. and Cox, K (1999). What factors support or prevent teachers from using ICT in their classrooms? Paper presented at the British Educational Research Association Annual Conference, University of Sussex, Brighton, November 1999.

Hult. M.. \& Lennung. S-A.. (1980). Towards a definition of action research: a note and a bibliography. Journal of Management Studies, 17, pp241-250. 
ISI (2000). Results of the Inspection of School X. Independent Schools Inspectorate: UK.

Klein, H.K., \& Myers, M.D., (1999). A set of principles for conducting and evaluating interpretive field studies in information systems. MISQ, Vol 23, No 1, March 1999, pp 6793.

Kock, N.F. Jr., McQueen, R.J., Scott, J.L. (1997). Can action research be made more rigorous in a positivist sense? The contribution of an iterative approach. Journal of Systems and Information Technology, 1, 1, pp 1-24.

Lee, A.S., (1999). Rigor and relevance in MIS research: beyond the approach of positivism alone. MISQ, Vol 23, No 1, March 1999, pp 29-33.

Leedy, P.D. (1993). Practical Research: planning and design. (5th Ed). Macmillan, New York.

McDougall, A., and Squires, D., (1997). A framework for reviewing teacher professional development programmes in information technology. Journal of Information Technology for Teacher Education, 6, 2, 1997.

Mumtaz, S (2000). Factors affecting teachers use of information and communications technology: a review of the literature. Journal of Information Technology for Teacher Education, 9, 3, 2000.

National Grid for Learning (2001). Impact2: Emerging findings from the evaluation of the impact of information and communications technologies on pupil attainment. : DfES. Annesley.

National Statistics (2000).

O'Mahony, C.D., Wild, P., Selwood, I.D., Reyes, M.G., Kraidej, L. (1996). Evaluation strategy for ITEM quality. In Information Technology in Educational Management for the Schools of the Future, Fung, A.C.W. et al (eds). Chapman \& Hall, London.

O'Mahony, C.D., (2000). The evolution and evaluation of information systems in NSW Secondary schools in the 1990s: the impact of values on information systems. PhD Thesis (unpublished): Macquarie University, NSW.

O'Mahony, C.D. (2001). I.S. Management in Schools - evolving towards integration. Proceedings: UK Academy of Information Systems Annual Conference (UKAIS2001), University of Portsmouth, April 2001.

Research Machines PLC (2000). The RM G7 (8) Report 2000 comparing ICT provision in Schools. RMplc, Abingdon.

SCHOOL X (2001). School X ICT Action Plan 2001-2. (Unpublished).

Selwood, I.D., Smith, D., \& Wisehart, J. (2000). Supporting teachers through the National Grid for Learning. In Pathways to institutional improvement with information technology in educational management, Nolan, C.J.P., Fung, A.C.W. \& Brown, M.A. (eds). Kluwer, Boston.

Stevenson Committee (1997). Information and Communications Technology in UK Schools An Independent Enquiry (The Stevenson Report). Pearson, London. Or rubble.ultralab.anglia.ac.uk/stevenson/ contents.html

Visscher, A.J. and Brandenhorst, E.M. (2000). How should school managers be trained for managerial school information system usage? In Pathways to institutional improvement with information technology in educational management, Nolan, C.J.P., Fung, A.C.W. \& Brown, M.A. (eds). Kluwer, Boston.

Watson, D., Blakeley, B., Abbott, C., (1998), Researching the use of communication technologies in teacher education. Computers and Education, 30, pp15-22. 